\title{
The External Finance Premium in Brazil: Empirical Analyses Using State Space Models*
}

\author{
Fernando Nascimento de Oliveira**
}

\begin{abstract}
Our objective in this paper is to estimate the external finance premium (EFP), which is a non-observable variable, of Brazilian firms using state space models. For this purpose, we built an original database with confidential and public data containing balance sheet information of 5,026 public and private firms from the third quarter of 1994 to the fourth quarter of 2010. Our results show that the EFP average and volatility of financially constrained firms are higher than those of non-financially constrained firms and that EFP is more sensitive to monetary policy for financially constrained firms than for nonfinancially constrained ones. This body of empirical evidence points to the importance of the balance sheet channel of the monetary transmission mechanism in Brazil.
\end{abstract}

Keywords: External Finance Premium, State Space Models, Kalman Filter, Monetary Transmission Mechanism, Balance Sheet Channel.

JEL Codes: G30, G32.

\footnotetext{
* Submitted in October 2014. Revised in May 2015.

${ }^{* *}$ Banco Central do Brasil, and IBMEC/RJ, Brazil. E-mail: fernando.nascimento@bcb.gov. br
}

Brazilian Review of Econometrics v. $36, \mathrm{n}^{\circ} 1$, pp. $97-131$ May 2016 


\section{Introduction}

External finance premium, henceforth EFP, defined as the difference between the cost of raising funds externally and the opportunity cost of using internal funds, is a fundamental variable in economics. While internal finance is available relatively cheaply, obtaining external funds through loans, bonds, or equity possibly implies substantial costs.

EFP is a crucial variable to understand several microeconomic decisions made by firms, such as capital structure, dividend and compensation policies, and demand for investment, among others. It is also important in a macroeconomic context because it is the key variable related to the credit channels of monetary transmission mechanisms, like the bank lending and balance sheet channels. ${ }^{1,2}$

However, as discussed by Bernanke and Gertler (1995), a major problem for empirical studies related to EFP is that it is a non-observable variable. There are currently two approaches in the literature that tackle this problem.

The first approach relies on finding readily available financial market indicators that are arguably good indicators for EFP, such as corporate bond spreads. The fact that these indicators have substantial predictive content for business cycle fluctuations is often understood as evidence for the existence of financial frictions, as argued by Gertler and Gilchrist (1994) and Mody and Taylor (2004). ${ }^{3}$

Another approach is adopted by Levin et al. (2004), who use microeconomic financial frictions along with balance sheet and bond market data to estimate the EFP for a group of listed firms in the USA. ${ }^{4}$

In this paper, we contribute to the literature by taking a different approach from the one mentioned above to estimate EFP. We estimate it for Brazilian private and public firms using a state space framework. The EFP for each one of the firms in our database is a smooth Kalman filter of the state variable. In our estimation of the state space model, we use several signal and control variables related to financial indicators of the firms highly correlated with credit market imperfections. ${ }^{5}$

\footnotetext{
${ }^{1}$ Credit channel theories can be broken down into two distinct theories: the bank lending and the balance sheet theories. In the former, monetary contractions increase the adverse selection problems between firms and banks, which may decrease the volumes of loans from banks to firms and households. The balance sheet channel of monetary policy arises because policy shifts affect not only market interest rates, but also the borrowers' financial positions, both directly and indirectly.

${ }^{2}$ The credit channel considers the existence of a financial premium, that is, a difference between the cost of funds raised externally (issued by equity or debt) and the opportunity costs of funds raised internally (by retaining earnings). The size of the external finance premium reflects imperfections in credit markets. The explanation of the dynamics of this premium can improve the timing and strength of monetary policy provided by traditional mechanism.

${ }^{3}$ Bernanke and Gertler (1995) use the inverse of coverage ratio.

${ }^{4}$ There is a vast empirical literature that uses one of these approaches. See Graeve (2008) for a good discussion about this literature and about EFP in the USA.

${ }^{5}$ Ogawa and Iiboshi (2008) estimate the EFP of Japanese firms using the Kalman Filter, but
} 
To achieve our objectives, we use an original and confidential database composed of unbalanced balance sheet and financial information of 291 public firms and 4,735 private firms. Among the private firms, 102 disclose quarterly information while all the others disclose only end-of-the-year information. ${ }^{6}$ The information about the public firms comes from Comissão de Valores Imobiliários (CVM) and Economatica, the information on private firms comes from Valor Econômico, and confidential data are obtained from SERASA and Gazeta Mercantil. ${ }^{7,8}$

We think that by putting public and private firms together in our database, we can have a better understanding of EFP in Brazil. Brazil is not too different from many industrial and emerging economies where the equity market is underdeveloped relative to the scale of the economy. Many important private firms in Brazil in terms of revenues, earnings, or number of employees refrain from going public. These private firms are, in many aspects, similar to many public firms. ${ }^{9}$ One possible explanation for this is the fact that the lack of enforcement of minority property rights makes it more difficult for firms to gain the investor's trust.

We choose the Kaplan and Zingales (1997) index (henceforth KZ) as our criteria to classify firms as financially constrained or non-financially constrained. We verify that this index is highly correlated to other financial characteristics of firms that indicate the degree in which firms access the financial markets.

Our results show that financially constrained firms in Brazil have much higher EFP average and volatility than firms that are not financially constrained. The EFP of financially constrained firms is much more elastic to the interest rate than the EFP of non-financially constrained firms. We also find that the elasticity of inventories, short-term debt, and net operating revenues, all of them as a proportion of total assets relative to EFP, is higher for financially constrained firms than for non-financially constrained ones. Finally, we have empirical evidence that these elasticities decrease in the case where the firm has an outstanding loan with Brazil's development bank, Banco Nacional de Desenvolvimento Social (BNDES), in our sample period. Our results seem robust to different specifications of the state space models. Therefore, our empirical evidence indicates the relevance of

\footnotetext{
their specification is quite different from ours.

${ }^{6}$ All public corporations disclose quarterly balance sheet information. We use their consolidated balance sheet information.

${ }^{7}$ SERASA is a privately held company that has one of the largest databases of financial and accounting information of firms and individuals in the world. The data are related to debt of firms and individuals in Brazil. The information collected by SERASA is provided to banks, to trade shops, small, medium and large companies, with the goal of giving support to credit decisions, thus making business cheaper, faster, and more reliable. The data from SERASA go from 1998 to 2007 and are both quarterly and annual.

${ }^{8}$ The data from Gazeta Mercantil are annual and go from 1998 to 2007 and are based on the balance sheet information of private firms published in this newspaper. The information from Valor Econômico is annual and goes from 2009 to 2010 and is based on the balance sheet information available on the 1000 Maiores Empresas publication.

${ }^{9}$ See Annual Survey of the Industry IBGE, www.ibge.gov.br.
} 
the balance sheet explanation of the monetary transmission mechanism in Brazil.

Brazil is a very special case of an emerging market where asymmetries of information could play a very important role in the transmission mechanism of monetary policy. Brazil has a very interesting financial system. In some of its aspects, such as its means of payments, the Brazilian financial system rivals that of developed countries. However, as far as volume of credit to households and firms and depth of the capital markets is considered, Brazil still lags behind OECD countries. $^{10}$

The cost of capital in Brazil is very high when compared to international standards. The spread banks charge on their loans, even for very well rated companies, is well above the spreads charged worldwide. This high cost of capital creates enormous agency costs between private agents and financial institutions. ${ }^{11}$

Another very important characteristic of corporations in Brazil is that, due to the high costs of capital, many of them look for a public development bank (BNDES - Brazilian Social and Economic Development Bank) - for long-term financing. Not only are interest rates much lower, but also maturities are much longer. Monetary policy affects only indirectly the long-term interest rates set by the BNDES in its loans.

There is a vast literature, both empirical and theoretical, on EFP. Most papers focus on the macroeconomic aspects of EFP. Just to cite some empirical papers, we have that of Gertler and Gilchrist (1994), who use the inverse of the coverage ratio as a proxy for the EFP of firms in the USA. Gertler and Gilchrist conclude that balance sheet effects can be more relevant for smaller firms (defined by the relative size of its total assets in relation to large firms).

Oliveira (2009) conducts a similar work to that of Gertler and Gilchrist (1994) for Brazil, also adopting firm's size as a measure of credit market access. The empirical analyses were conducted over a database of public and private firms between the third quarter of 1994 and the fourth quarter of 2007. Similarly to Gertler and Gilchrist (1994), Oliveira concludes that smaller firms are more sensitive to EFP than large firms.

Oliveira and Ronchi (2012) empirically analyze the relationship between the EFP of non-financial corporations in Brazil with their default probability and with their demand for inventories. They find that corporations with a greater EFP have a greater probability of default.

Gilchrist and Himmelberg (1995), Gilchrist and Hilmlberg (1998) investigate the influence of fundamental (expected return and present value) and financial (availability of internal and external funds) factors on firms' investment decisions considering capital market imperfections. Among other characteristics, the authors adopt the existence of debt rating as a criterion to measure credit market

\footnotetext{
${ }^{10}$ The total credit to the private sector is around $50 \%$ of GNP, while in the USA, for example, it is over $100 \%$ of GNP.

${ }^{11}$ This is how the literature defines credit market imperfections in general terms.
} 
imperfections. According to the authors, considering that most companies that issue public debt obtain a bond rating, this strategy permits splitting the sample into firms that did, or did not, issue public debt in the past. If the company did not issue any debt, it must have faced more constraints in credit market access. Their empirical analyses indicate that non-rating firms are more sensitive to EFP than large firms.

Our paper is also in line with a vast empirical literature about investment cash flow sensitivities. ${ }^{12}$ The findings of this literature stress that these sensitivities are more relevant for financially constrained firms. We think that the results of our paper confirm these results and also provide a possible justification related to the fact that the EFP of financially constrained firms is much higher than that of non-financially constrained ones.

The remainder of this paper is organized as follows. Section 2 describes the data. Section 3 presents our model. Section 4 presents the empirical analyses. Section 5 concludes.

\section{Data}

We built an original and confidential database of an unbalanced panel of balance sheet information of 291 public firms and 4,735 private firms from the third quarter of 1994 to the fourth quarter of 2010. Among the private firms, 102 disclose quarterly information while all the others disclose only end-of-the-year information. ${ }^{13}$ The information on public firms comes from Comissão de Valores Imobiliários (CVM) and Economatica, the information on private firms comes from Valor Econômico, and confidential data come from SERASA and Gazeta Mercantil.

Panel A of Table 1 shows the number of firms in our database sorted into private and public. As one can see, the services sector is predominant for public firms $(13.40 \%)$ and private firms $(62.00 \%)$.

Panel B of Table 1 shows the financial characteristics of all firms by sectors of the economy. As one can verify, the sector with the highest average of Tobin's Q is the Chemical and Petroleum sector (1.13), while the ones with the highest average of Cash Flow/Assets and Leverage are Services (0.16) and Mining and Metallurgy (0.68), respectively. ${ }^{14}$

\footnotetext{
${ }^{12}$ See Fazzari et al. (1988), Kaplan and Zingales (1997), and Asker et al. (2015).

${ }^{13}$ All public corporations disclose quarterly balance sheet information. We use their consolidated balance sheet information.

${ }^{14}$ The definition of Tobin's Q follows FHP (1988). Tobin's Q is:$$
Q=\frac{(V+B-N)}{K}
$$

$V, B$ and $N, K$ correspond, respectively, to market share of firms' stocks, debt, inventories, and stock of capital at the beginning of the period. The variable cash flow, in turn, was calculated as the sum of the firm's net income (after interest and taxes) and all deductions levied on non-
} 
Panel $\mathrm{C}$ of Table 1 shows the financial characteristics of firms sorted according to quarterly and annual data. Firms with only quarterly data are, on average, bigger, more profitable, invest more, and distribute more dividends than firms with only annual data. We also conduct a mean test of the averages of these series — which we do not report due to space restrictions - that confirm these observations.

Panel D of Table 1 presents information about outstanding BNDES loans taken out by the firms during the sample period. As one can see, there are 106 firms $(21.09 \%)$ with outstanding loans. Most of them belong with the food and beverages sector $(16.98 \%) .{ }^{15}$

Table 1

Descriptive Analysis of the Database

Our sample of firms is composed of 291 non-financial public corporations and 4,735 private firms Our sample period goes from the third quarter of 1994 to the fourth quarter of 2010. Among the private firms, 102 disclose quarterly information as well as yearly information while all the others disclose yearly information only. The information on public corporations comes from Comissão de Valores Mobiliários (CVM) and Economatica, the information on private firms comes from Valor Econômico, and confidential information is obtained from SERASA and Gazeta Mercantil. Panel A shows the number of private and public firms in our database. Panel B shows the financial characteristics of all firms by sectors of the economy. Panel C shows the financial characteristics of firms according to quarterly and annual data. Panel D presents information about outstanding BNDES loans taken out by the firms during the sample period.

\begin{tabular}{lcc}
\multicolumn{2}{c}{ Panel A - Total Number of Firms Classified by Type (private or public) and Sectors } \\
\hline & Public & Private \\
\hline Chemical/Petroleum & 36 & 273 \\
Foods and Beverage & 40 & 90 \\
Mining/Metallurgy & 8 & 31 \\
Eletrical/Eletronic equipment & 14 & 92 \\
Transportation & 18 & 268 \\
Public Services & 30 & 91 \\
Textile & 35 & 75 \\
Services & 39 & 2,924 \\
Others & 71 & 2,001 \\
Total & 291 & 4,735 \\
\hline
\end{tabular}

financial revenue, such as depreciation and amortization.

${ }^{15}$ To obtain information on BNDES, we looked at public firms' off-balance sheet information as well as at the information disclosed on the BNDES webpage. 


\begin{tabular}{lcccccc} 
Panel B - Financial Indicators by Sectors of the Economy \\
\hline
\end{tabular}

\begin{tabular}{|c|c|c|c|c|c|c|c|c|}
\hline \multirow[b]{2}{*}{$\begin{array}{l}\text { Financial } \\
\text { Characteristics }\end{array}$} & \multicolumn{4}{|c|}{ Quarterly Data } & \multicolumn{4}{|c|}{ Annual Data } \\
\hline & $\mathrm{N}$ & Mean & Median & $\begin{array}{l}\text { Standard } \\
\text { Deviation }\end{array}$ & $\mathrm{N}$ & Mean & Median & $\begin{array}{l}\text { Standard } \\
\text { Deviation }\end{array}$ \\
\hline Log (Assets) & 393 & 18.31 & 18.05 & 4.19 & 4735 & 17.17 & 17.05 & 3.51 \\
\hline Operating Revenues/Assets & 393 & 0.68 & 0.6 & 0.85 & 4735 & 0.36 & 0.18 & 0.58 \\
\hline Financial Expenses/Assets & 393 & 0.19 & 0.18 & 0.35 & 4735 & 0.19 & 0.19 & 0.42 \\
\hline Fixed Assets/Assets & 393 & 0.47 & 0.53 & 0.46 & 4735 & 0.36 & 0.36 & 0.83 \\
\hline Short-term Debt/Assets & 393 & 0.68 & 0.65 & 0.91 & 4735 & 0.49 & 0.17 & 0.15 \\
\hline Long-term Debt/Assets & 393 & 0.23 & 0.19 & 0.17 & 4735 & 0.09 & 0.12 & 0.13 \\
\hline Capex/Assets & 393 & 0.076 & 0.082 & 0.01 & 4735 & 0.067 & 0.068 & 0.14 \\
\hline $\mathrm{Q}$ & 393 & 1.35 & 1.39 & 0.21 & 4735 & 1.23 & 1.58 & 0.03 \\
\hline Cash Flow/Assets & 393 & 0.13 & 0.124 & 0.32 & 4735 & 0.1 & 0.12 & 0.05 \\
\hline ROA & 393 & 0.15 & 0.13 & 0.11 & 4735 & 0.1 & 0.14 & 0.001 \\
\hline Payout ratio & 393 & 0.27 & 0.24 & 1.46 & 4735 & 0.18 & 0.23 & 0.53 \\
\hline BNDES Loans & 62 & & & & & & & \\
\hline
\end{tabular}

Panel D - Outstanding BNDES Loans during the Sample Period

\begin{tabular}{cc}
\hline Sector & Number of Firms \\
\hline Foods and beverages & 18 \\
Retail & 7 \\
Construction & 6 \\
Electro-electronics & 3 \\
Industrial Machinery & 3 \\
Mining & 4 \\
Non-Metallic minerals & 0 \\
Pulp and paper & 5 \\
Oil and Gas & 6 \\
Chemical & 11 \\
Metallurgy and steelmaking & 11 \\
Textile & 9 \\
Transportation & 6 \\
Vehicles and Spare Parts & 3 \\
Agriculture and fisheries & 0 \\
Others & 17 \\
Total & 106 \\
\hline
\end{tabular}


We now present the classification of firms with respect to their access to financial markets using the Kaplan and Zingales (KZ) (1997) index. We follow KZ (1997) classification scheme and use both subjective and objective criteria. We rank firms on an ordinal scale, five groups, from least- to most-obviously financially constrained. Then, we estimate an ordered regression, which relates our ranking to the following variables: Q, leverage, cash flow/total assets, cash balances, dividends/total assets, and a dummy that indicates that the firm had an outstanding BNDES loan in our sample period. Thus, the parameters estimated in this regression allow us to create a synthetic "KZ index" of financial constraints for a non-financially constrained sample of firms. ${ }^{16}$

To build our index, we collect, in the case of public firms, financial statements, notes of financial statements, information on bankruptcy, and information from the firm's department of investors. In the case of private firms, we use our balance sheet information only.

The first group contains firms we think are non-financially constrained. We place a firm in this category if it initiated or increased the payout ratio, repurchased stock, or if its cash reserves were above the 70th percentile in at least one quarter or year of our sample period, were never below the 30th percentile in any quarters or years, or had an outstanding BNDES loan.

The second group includes firms we find more unlikely to be financially constrained. These firms tend to have sizable cash reserves, unused lines of credit, and high interest coverage. Therefore, in this category, the quantitative measures of a typical firm would be interest rate coverage and cash reserves between the 60th and 70th percentiles in all quarters or years of our sample period, and possibly an outstanding BNDES loan.

The third group includes firms we find difficult to classify as either financially or non-financially constrained. Frequently, these firms face an adverse product market environment, but they are not explicitly strapped for cash. This category also includes firms that provide contradictory indications of their financial situation. These firms would tend to have sizable cash reserves, unused lines of credit, and high interest coverage. In terms of quantitative measure, we put a firm in this category if its cash and interest rate coverage were between the 50 th and 60 th percentiles in all quarters or years of our cross-sectional distribution and if the firm did not present any outstanding BNDES loan.

The fourth group includes firms we consider more likely to be financially constrained. These firms do not tend to have sizable cash reserves, unused lines of credit, and high interest coverage. Firms in this category would have interest rate coverage and cash reserves between the 30th and 50th percentiles and no outstanding BNDES loan.

The fifth group contains firms we think are undoubtedly financially constrained. We place a firm in this category if it declared bankruptcy during our sample

\footnotetext{
${ }^{16}$ See Lamont, Polk and Saa-Requejo (2001).
} 
period, was cut out of its usual source of credit, is renegotiating debt payments, or declares that it is forced to reduce investments because of liquidity problems. In more quantitative measures, the firm would experience its cash and interest coverage ratio below the 30th percentile in at least one quarter or year of our sample period, would never have them above the 70th percentile, and would have no outstanding BNDES loans.

Panel A of Table 2 presents the results of the estimated ordered equation. As one can easily observe, the estimated coefficients have the appropriate signs and are all statistically significant for the quarterly data: the positive ones include Tobin's Q, cash flow/assets, and BNDES and dividends/assets; the negative one includes the leverage coefficient. Both the sign and statistical significance of the BNDES coefficient are noteworthy, providing another piece of evidence of the importance of BNDES for investment in Brazil.

We consider a firm as non-financially constrained if the predicted $\mathrm{KZ}$ is above the 70th percentile in at least one quarter or year of our sample period and if it has never been below the 30th percentile in any quarters or years. We consider firms to be financially constrained if the predicted $\mathrm{KZ}$ is below the 30 th percentile in any quarter or year of our sample period and if it has never been above the 70th percentile in any quarters or years.

Panel B of Table 4 lists the mean, median, and standard deviation values of some financial characteristics of financially constrained and non-financially constrained firms with quarterly data using the predicted KZ. We have 78 nonfinancially constrained and 182 financially constrained firms according to this classification. As we can easily verify, non-financially constrained firms have, on average, greater long and short-term debt than financially constrained firms. Nonfinancially constrained firms also have more fixed assets and net operating revenues as a percentage of total assets. Finally, 42 non-financially constrained firms have outstanding BNDES loans compared to only 10 financially constrained firms.

Panel C of Table 4 shows the end-of-the-year information on financially constrained and non-financially constrained private firms. We have 152 non-financially constrained and 582 financially constrained firms. As we can easily verify, nonfinancially constrained firms have, on average, greater long and short-term debt than their financially constrained counterparts. Non-financially constrained firms also have more fixed assets and net operating revenues as a percentage of total assets. Finally, 37 non-financially constrained firms have outstanding BNDES loans compared to only eight financially constrained ones. 
Table 2

Classification of Financially and Non-financially Constrained Firms: Kaplan and Zingales (1997)

We follow Kaplan and Zingales (1997). We rank firms on an ordinal scale, five groups, from leastto most-obviously financially constrained. To build our index, we collect, in the case of public firms, financial statements, notes of financial statements, information on bankruptcy, and information from the department of investors. In the case of private firms, we use balance sheet information only. The first group contains firms we think are non-financially constrained. We place a firm in this category if it initiated or increased the payout ratio, repurchased stock, or if its cash reserves were above the 70 th percentile in at least one quarter or year of our sample period and were never below the 30th percentile in any quarters or years, or had an outstanding BNDES loan. The second group includes firms which are more unlikely to be financially constrained. These firms tend to have sizable cash reserves, unused lines of credit, and high interest coverage. Therefore, in this category, the quantitative measures of a typical firm would be interest rate coverage and cash reserves between the 60th and 70th percentiles in all quarters or years of our sample period, and possibly an outstanding BNDES loan. The third group includes firms we find difficult to classify as either financially or non-financially constrained. Frequently, these firms face an adverse product market environment, but they are not explicitly strapped for cash. This category also includes firms that provide contradictory indications of their financial situation. These firms would tend to have sizable cash reserves, unused lines of credit, and high interest coverage. In terms of quantitative measure, we put a firm in this category if its cash and interest rate coverage were between the 50th and 60th percentiles in all quarters or years of ou cross-sectional distribution and if the firm did not present any outstanding BNDES loan. The fourth group includes firms we consider more likely to be financially constrained. These firms do not tend to have sizable cash reserves, unused lines of credit, and high interest coverage. Firms in this category would have interest rate coverage and cash reserves between the 30th and 50th percentiles in our database and no outstanding BNDES loan. The fifth group contains firms we think are undoubtedly financially constrained. We place a firm in this category if it declared bankruptcy during our sample period, was cut out of its usual source of credit, is renegotiating debt payments or declares that it is forced to reduce investments because of liquidity problems. In more quantitative measures, the firm would experience its cash and interest coverage ratio below the 30th percentile in at least one quarter or year of our sample period, never had them above the 70th percentile, and had no outstanding BNDES loans. We consider a firm to be non-financially constrained if the predicted KZ is above the 70th percentile in at least one quarter or year of our sample period and if it has never been below the 30th percentile in any quarters or years. We consider firms to be financially constrained if the predicted KZ is below the 30th percentile in any quarter or year of our sample period and if it has never been above the 70th percentile in any quarters or years. Panel A of Table 4 presents the results of the estimated ordered equation. Panel B of Table 4 lists the mean, median, and standard deviation values of some financial characteristics of financially constrained and non-financially constrained firms with quarterly data using the predicted KZ. Panel C of Table 4 shows the financially constrained and non-financially constrained private firms with end-of-the-year information.

\begin{tabular}{lcc}
\hline Panel A - Ordered Equation of KZ (1997) & \\
\hline & Quarterly & Annual \\
\hline Cash Flowt/Assetst-1 & 1,14 & 1,35 \\
& $(0.01)$ & $-0,43$ \\
Divt/Assetst-1 & 13.16 & 15,68 \\
& $(0.04)$ & $-0,06$ \\
Leverage & $-3,25$ & $-0,44$ \\
& $(0.01)$ & $-0,05$ \\
Q-1 & 1.74 & 2,38 \\
& $(0.01)$ & $-0,19$ \\
BNDES & 0.09 & 0,23 \\
& $(0.021)$ & $-0,12$ \\
Cash/Assets & 1.69 & 0,41 \\
& $(0.08)$ & $-0,08$ \\
Control Variables & & \\
\multirow{2}{*}{ Sample } & & \\
\hline
\end{tabular}




\begin{tabular}{|c|c|c|c|c|c|c|c|c|}
\hline \multirow[b]{2}{*}{$\begin{array}{l}\text { Financial } \\
\text { characteristics }\end{array}$} & \multicolumn{4}{|c|}{$\begin{array}{l}\text { Non restricted } \\
\text { (A) }\end{array}$} & \multicolumn{4}{|c|}{$\begin{array}{l}\text { Restricted } \\
\text { (B) }\end{array}$} \\
\hline & $\mathrm{N}$ & Mean & Median & $\begin{array}{l}\text { Standard } \\
\text { deviation }\end{array}$ & $\mathrm{N}$ & Mean & Median & $\begin{array}{l}\text { Standard } \\
\text { deviation }\end{array}$ \\
\hline Log (Assets) & 78 & 11.87 & 11 & 3.51 & 182 & 8.32 & 8.7 & 4.76 \\
\hline Operating Revenues/Assets & 78 & 0.61 & 0.42 & 2.65 & 182 & 0.31 & 0.47 & 0.49 \\
\hline Financial Expenses/Assets & 78 & 0.15 & 0.05 & 1.28 & 182 & 0.19 & 0.16 & 0.29 \\
\hline Fixed Assets/Assets & 78 & 0.63 & 0.35 & 0.43 & 182 & 0.47 & 0.31 & 0.61 \\
\hline Short-term Debt/Assets & 78 & 0.41 & 0.41 & 0.61 & 182 & 0.39 & 0.14 & 0.51 \\
\hline Long-term Debt/Assets & 78 & 0.32 & 0.05 & 0.31 & 182 & 0.28 & 0.23 & 0.29 \\
\hline Capex/Assets & 78 & 0.074 & 0.062 & 0.003 & 182 & 0.042 & 0.061 & 0.003 \\
\hline & 78 & 1.03 & 1.08 & 0.004 & 182 & 0.48 & 0.38 & 0.124 \\
\hline Cash Flow/Assets & 78 & 0.143 & 0.166 & 0.001 & 182 & 0.131 & 0.134 & 0.035 \\
\hline BNDES Loans & 42 & & & & 10 & & & \\
\hline
\end{tabular}

\begin{tabular}{|c|c|c|c|c|c|c|c|c|}
\hline & \multicolumn{4}{|c|}{$\begin{array}{c}\text { Non restricted } \\
(\mathrm{A})\end{array}$} & \multicolumn{4}{|c|}{$\begin{array}{c}\text { Restricted } \\
\text { (B) }\end{array}$} \\
\hline $\begin{array}{l}\text { Financial } \\
\text { characteristics }\end{array}$ & $\mathrm{N}$ & Mean & Median & $\begin{array}{l}\text { Standard } \\
\text { deviation }\end{array}$ & $\mathrm{N}$ & Mean & Median & $\begin{array}{l}\text { Standard } \\
\text { deviation }\end{array}$ \\
\hline Log (Assets) & 152 & 17.43 & 16.76 & 4.3 & 582 & 17.14 & 16.30 & 3.51 \\
\hline Operating Revenues/Assets & 152 & 0.61 & 0.64 & 0.84 & 582 & 0.30 & 0.10 & 0.54 \\
\hline Financial Expenses/Assets & 152 & 0.18 & 0.18 & 0.36 & 582 & 0.16 & 0.17 & 0.44 \\
\hline Fixed Assets/Assets & 152 & 0.40 & 0.56 & 0.41 & 582 & 0.31 & 0.34 & 0.81 \\
\hline Short-term Debt/Assets & 152 & 0.61 & 0.67 & 0.92 & 582 & 0.44 & 0.16 & 0.21 \\
\hline Long-term Debt/Assets & 152 & 0.24 & 0.19 & 0.14 & 582 & 0.03 & 0.10 & 0.31 \\
\hline Capex/Assets & 152 & 0.048 & 0.053 & 0.012 & 582 & 0.031 & 0.032 & 0.013 \\
\hline & 152 & 0.87 & 1.08 & 0.003 & 582 & 0.30 & 0.12 & 0.18 \\
\hline Cash Flow/Assets & 152 & 0.12 & 0.12 & 0.024 & 582 & 0.18 & 0.12 & 0.021 \\
\hline BNDES Loans & 37 & & & & 8 & & & \\
\hline
\end{tabular}

In what follows, we describe our state space model.

\section{The State Space Model}

In the presence of asymmetric information between lenders and borrowers, financial arrangements arise to prevent borrowers from acting against the interests of lenders. In addition, lenders can monitor the borrowers' behavior to enforce such arrangements. The resulting agency cost caused by this inefficiency drives a wedge between the cost of internal and external funds, known as EFP.

The main difficulty in conducting an empirical study of EFP is the nonobservability of the agency cost faced by borrowers. Therefore, some kind of proxy was used in previous studies to represent the movement of agency cost. Anyway, all of these studies have some type of drawback. To try to circumvent this, we estimate EFP using a Kalman Filter in a state space model.

We consider that a Kalman Filter in a state space model is an interesting empirical alternative to estimate EFP. It is widely used in many other areas of Economics and Finance to estimate variables that are not observable. Ogawa and Iiboshi (2008) also estimate EFP for Japanese firms using the Kalman Filter in a state space framework. In our paper, the model specification is quite different from theirs.

We have an unbalanced panel database of balance sheet information on Brazilian private and public firms. We will consider the EFP of each firm in our database 
as a time-varying fixed effect of this firm. ${ }^{17}$ To estimate it, we structure the unbalanced panel in a state space framework. The EFP of each firm will be a smooth Kalman filter of the state variable of this state space model corresponding to each firm. ${ }^{18}$

Following Oliveira (2009) and Gertler and Gilchrist (1994), we will model three signals: inventories divided by total assets, short-term debt divided by total assets, and net operating revenues divided by total assets. Equations (1) to (3) below are the signal equations, where: $i$ indexes the firm from 1 to $5026 ; t$ indexes the quarter from 1994Q3 to 2010Q4; and the disturbance is white noise and independent across firms and time.

As an identification strategy for these equations, we assume (see Oliveira and Ronchi, 2012) that our signals are affected only by lags of EFP and not by its current value. We think that this is a reasonable assumption because it takes some time for inventories, debt, and operating revenues to adjust to the firm's financial conditions. This assumption will also be useful when we estimate the state space model, because it will allow us to circumvent endogeneity problems, which would make the estimation much more complicated.

$$
\begin{aligned}
& S_{i t}=a_{0}+\gamma\left(S_{i t-1}\right)+\chi L\left(E F P_{t}\right)+\delta L\left(S E L I C_{t}\right)+\eta F R+\varphi F R^{*} L\left(S E L I C_{t}\right) \\
& +\lambda F R^{*} B N D E S^{*} L\left(S E L I C_{t}\right)+\vartheta^{*} \text { fixedasset }_{i t-1}+\varepsilon_{i t}
\end{aligned}
$$

In equations (1) to (3), $R$ represents net operating revenues divided by total assets and $S$ stands for inventories divided by total assets, whereas in equation (4), $D$ denotes short-term debts divided by total assets. To control for the existence of agency costs, we use the fixed assets to total assets ratio in all equations. This ratio gives an idea of the level of collateral which firms can potentially have at hand to offer banks. The higher this ratio, the lower the agency costs. We also include the following variables: the $F R$ dummy variable, which indicates that the firm is financially constrained; interaction terms between the $F R$ variable and the lags of the SELIC rate ( $L$ is the lag operator and we use three lags for the SELIC rate); interaction terms between $F R$, BNDES, and SELIC rate (again, we use

\footnotetext{
${ }^{17}$ Peyrache and Rambaldi (2012) did something similar for the time-varying fixed effect of the production function in Australia.

${ }^{18}$ See Harvey (1994) for an excellent introduction to state space models and Kalman filters.
} 
three lags for the SELIC rate), indicating that a financially constrained firm had outstanding BNDES debt during our sample period. ${ }^{19,20}$

To build our state equation and find the EFP as a state variable for each firm, we need to understand which financial variables can explain EFP in Brazil. In what follows, we describe a theoretical model that can explain which financial variables are relevant in the Brazilian case.

Our model will be a partial equilibrium and static one related to the optimal decision of capital level of a Brazilian firm so as to maximize the expected profit. We have a continuum of firms. The main idea comes from Bernanke et al. (1999) (BGG). The BGG model incorporates the costly state verification (CSV) mechanism.

In the BGG model, there is only one lender (a market lender). In our model, we include a second lender, a Social Development Bank (BNDES) that lends at a lower interest rate than the market lender.

The reason for this is a particular feature of Brazil's credit market, as we stressed before. In Brazil, BNDES is a key player in the implementation of government's industrial policy and the main long-term financing provider for private investment. The funds offered by BNDES have better costs and maturity conditions compared with other financing agents from Brazil's credit market. Furthermore, the long-term interest rate charged for funds obtained from the development bank $^{21}$ are just marginally affected by the short-term interest rate controlled by the Central Bank. In such a context, firms that have more access to BNDES funds must be more resilient to EFP variation. ${ }^{22}$

We will assume that the probability for a firm to obtain a loan from BNDES is $P_{B}$. To apply for financing with BNDES resources, the client must meet the following minimum requirements: be up to date with tax obligations; have ability to pay; have sufficient guarantees against the risk of the operation; not be under a credit recovery regime; and comply with legislation on the imports, in the case of financing for imports of machinery and equipment; and finally comply with environmental laws.

The firms are assumed to be risk-neutral and have finite horizons. They acquire capital $K$ at a price $Q$ at the end of period $t$ for use in production in period $t+1$. At the end of period $t$, the firm $j$ has net worth $N_{t+1 j}$ available and finances capital with internal funds supplemented by external borrowing from a financial intermediary: $B_{t+1 j}=Q_{t+1} K_{t+1 j}-N_{t+1 j}$.

The ex-ante expected revenue from an investment project depends on whether

\footnotetext{
${ }^{19}$ We use robust standard errors and perform Im, Pesaran and Shin unit root test for panel data, which confirms that all series are stationary.

${ }^{20}$ We use up to three lags for the SELIC rate due to anecdotal evidence for the time it takes for the SELIC rate to affect the real sector of the economy in Brazil.

${ }^{21}$ TJLP - "Taxa de Juros de Longo Prazo" (Long-term Interest Rate).

22 On BNDES webpage, one can verify that the volume of loans and the number of firms that have received loans have increased over time, particularly in recent years.
} 
the lender obtained a loan from BNDES or at the market bank. It is given by $w_{B} R_{t+1}^{K} Q_{t} K_{t}$ in the case of the market bank and $w_{M} R_{t+1}^{K} Q_{t} K_{t}$ in the case of BNDES as a lender, where $w_{M}$ and $w_{B}$ are productivity disturbances for a firm that obtains a loan from the market lender and from BNDES, respectively. These disturbances are iid across firms and time.

By adopting the CSV approach, an agency problem arises, because intermediaries (market bank and BNDES) cannot observe $w_{M}, w_{B}$ and need to pay an auditing cost if they wish to observe the outcome. The financial contract is a standard debt contract including the following bankruptcy clause: if $w_{M}>\bar{w}_{M}$ or $w_{B}>\bar{w}_{B}$, the firm pays off the loan in full from revenues and keeps the residual. The lender receives $\bar{w}_{B} R_{t+1}^{K} Q_{t} K_{t}$ in the case of BNDES and $\bar{w}_{M} R_{t+1}^{K} Q_{t} K_{t}$ in the case of a market bank.

If the firm defaults on its loan, the lender pays an auditing cost $\mu_{B}$ in the case of BNDES and $\mu_{M}$ in the case of the market lender. BNDES receives what is found, namely $\left(1-\mu_{B}\right) \bar{w}_{B} R_{t+1}^{K} Q_{t} K_{t}$ and the market bank receives $\left(1-\mu_{M}\right) \bar{w}_{M} R_{t+1}^{K} Q_{t} K_{t}$. A defaulting firm receives nothing.

It is reasonable to assume that the lender will issue the loan only if the expected gross return to the firm equals the lender's relevant opportunity costs of lending. Because the loan risk is perfectly diversifiable, the lender's relevant opportunity cost is the riskless rate $R_{t+1}$ (SELIC rate) in the case of the market lender and $\rho R_{t+1} \rho<1$ in the case of BNDES.

Let $F_{B}(w)$ and $F_{M}(w)$ be the probability of default in the case of a firm that obtained a loan from BNDES and from the market bank, respectively. Let $s=E\left[\frac{R_{t+1}^{K}}{R_{t+1}}\right]$ be the discounted return on capital or the EFP.

The following propositions relate EFP to the firms' probability of default and to the probability a firm has to obtain a loan from BNDES.

Proposition 1. Considering the structure of the model defined above, EFP is an increasing function of firms' probabilities of default at BNDES and at the market lender.

Demonstration: See Appendix A.

Proposition 2. Considering the structure of the model defined above, EFP is a decreasing function of the firm's probability to obtain a loan at BNDES if the BNDES expected profit is less than that of the market lender.

Demonstration: See Appendix A.

By taking Propositions 1 and 2 above into consideration, EFP is related to the firms' probability of default and to their probability of obtaining a loan at BNDES. The probability of default is a function of agency costs that depend on leverage, on the return on capital, on the price of capital, and on default costs.

We follow Smith and Stuulz (1985) and take total debt divided by total assets as an empirical approximation to the leverage ratio. We also use the ratio between current assets and current liabilities. This variable shows the degree of the firm's current liquidity. Very liquid businesses will have less probability of bankruptcy. 
Myers (1977) demonstrates that indebted businesses have distorted incentives in terms of their policies for investment. In sum, distortion occurs due to the priority that the creditors have over shareholders for receiving cash flow generated by corporations. Given this priority, shareholders do not have incentives to contribute resources for investments whose returns - because of the high level of indebtedness - will likely be used in the payment of debt. Excessive debt, however, can prevent lucrative projects from being implemented. Thus, creditors anticipate the conflict of interest and incorporate their costs into the interest rate. We will use the SELIC rate, lagged one period.

As argued by Jensen and Meckling (1976), the higher the ratio between fixed assets and total assets, the greater the firm's capacity to offer real collateral to creditors, which can reduce creditors' loss from financial stress and, consequently, reduce the incentives to distort the investment policy. Therefore, a greater ratio between fixed assets and total assets reduces the probability of default.

Rajan and Zingales (1995) show that a high ratio between a corporation's market value and the book value suggests that future gains (embedded in the market value of the firm's shares) still do not correspond to the value of the existing assets. Such a corporation should have greater difficulty offering real collateral to creditors that is compatible with the profitability of the existing investment opportunities. Therefore, we will use this ratio as a control variable as well.

Size is another characteristic of a firm related to its agency cost with creditors. Larger firms, in general, have greater reputation, a fact that can reduce agency costs. Therefore, we can expect that size, determined by total assets, will reduce the probability of the firm using hedge or speculation, as explained by Rajan and Zingales (1995).

We also consider an explanatory variable that is related to both the costs of bankruptcy and the agency cost with creditors: the firm's profitability, as discussed by Rajan and Zingales (1995). The firm's profitability is defined as the ratio of the company's net revenue to its net worth. This variable gives an idea about the capacity of the corporation to finance itself with internal resources, avoiding the capital market or bank loans. The less a company needs to finance externally, the fewer are the costs of bankruptcy.

We also follow Bernanke and Gertler (1995) and use the inverse of the coverage ratio as a control variable for EFP.

In brief, EFP in our model will be a function of the following variables lagged one period so as to avoid problems of endogeneity: fixed assets divided by total assets; size, measured by a dummy variable equal to 1 if the firm is small; profitability, measured by net revenues divided by net worth; inverse of the coverage ratio; market value divided by book value; current assets divided by current liabilities; total debt divided by total assets; and a binary variable that indicates that the firm obtained an outstanding BNDES loan during our sample period and that interacts with the dummy small and the SELIC rate. 
Equation (4) below shows the state equation, where: $i$ indexes the firm from 1 to $5026 ; t$ indexes the quarter from 1994Q3 to 2010Q4; $L$ is the lag operator (we use three lags for the SELIC rate and for EFP); and the disturbance is white noise and independent across firms and time. ${ }^{23}$

$$
\begin{aligned}
E F P_{i t}=a_{0}+ & \tau L\left(E F P_{i t-1}\right)+\beta F R+\phi F R B N D E S_{i t}^{*} L\left(S E L I C_{t}\right) \\
& +\theta\left(F R^{*} L\left(S E L I C_{t}\right)+\kappa^{*} L\left(\text { SELIC }_{t}\right)+\Pi^{*} \text { Control }_{i t}+\varepsilon_{i t}\right.
\end{aligned}
$$

\section{Empirical Analysis}

One problem with estimating our state space model, equations (1) to (4), is that we do not have much available information on firms, particularly private firms with annual balance sheet information only. So, we backcast all control and signal series used in equations (1) to (4).

There are many techniques to do this. ${ }^{24}$ We follow Issler et al. (2009). In this case, missing values will be the state variables described by the smooth Kalman filter state variable of the model below, equation (7), for each variable of interest and for each firm $(i$ indexes the firm from 1 to 5026 and $t$ indexes the quarter from 1994Q3 to 2010Q4)..$^{25}$

$$
\begin{aligned}
\Delta I_{i t} & =\Delta S_{i t} \text { for } t=1994 Q 3 \text { to } 2010 Q 4 \Delta I_{t} \text { missing } \\
\Delta I_{i t} & =\Delta I_{i t} \text { otherwise } \\
\Delta S_{i t} & =\alpha \Delta S_{i t-1}+B X_{i t}+\varepsilon_{i t}
\end{aligned}
$$

where,

$\Delta I$ - series of interest used as control or signal in our state space from (3) to (6) measured as growth rate;

$X$ - control variables: growth rate of real GDP, growth rate of real industrial production, and growth rate of services GDP;

$\Delta S$ - state variable at $t$;

$\varepsilon_{i t}$ - White noise, $\alpha$ is a constant parameter and $B$ is a matrix of constant parameters.

In all our estimations of state space models, we perform several diagnostic tests. We use the Jarque and Bera (1980) test for normality; we assess independence of the errors according to Brock et al. (1996); and we verify the existence of outliers and structural breaks with the residual series of the signals and state equations and choose the number of lags in both the state and signal equation using Akaike (1981) information criteria. ${ }^{26}$

\footnotetext{
${ }^{23}$ The number of lags for each firm is obtained by the Akaike information criteria. $L$ represents the lag function and $\Pi$ is a matrix of constant coefficients over time.

${ }^{24}$ See Chow and Lin (1971), Harvey and Pierce (1984), and Silva and Cardoso (2001).

${ }^{25}$ We use the fit of the $R^{2}$ in first differences as a measure of fit, as defined in Issler et al. (2009).

${ }^{26}$ We do not reject normality and independence in most of the state space models we estimate.
} 
After backcasting our controls and signal series, we estimate our state space model, equations (5) to (6). The EFP for each firm is the smooth Kalman filter vector of state equation (6) for each firm.

Table 3 presents the EFP averages and volatilities estimated for several classifications of firms. One can observe that financially constrained firms in our sample have higher EFP average and volatility than non-financially constrained firms, regardless of whether they have quarterly or annual information or had outstanding BNDES loans during our sample period. ${ }^{27}$

Table 3

EFP Means and Means Tests

Our sample is composed of 291 non-financial public corporations and 4,735 private firms. Our sample period goes from the third quarter of 1994 to the fourth quarter of 2010. Among the private firms, 102 disclose quarterly information as well as yearly information while all the others disclose yearly information only. The information on public corporations comes from the Brazilian Securities and Exchange Commission (CVM) and Economatica, the information on private firms comes from Valor Econômico, and confidential information comes from SERASA and Gazeta Mercantil. We consider a firm as non-financially constrained if the predicted $\mathrm{KZ}$ is above the 70th percentile in at least one quarter or year of our sample period and if it has never been below the 30th percentile in any quarters or years. We consider firms to be financially constrained if the predicted $\mathrm{KZ}$ is below the 30th percentile in any quarter or year of our sample period and if it has never been above the 70th percentile in any quarters or years. The table presents the means, means difference, and means difference tests for EFP between large and small firms. The first two columns of Panel A show the standard deviations in parentheses. The third column displays the $p$-values of the $t$ tests in parentheses.

\begin{tabular}{lccc}
\hline & EFP NFR & EFP FR & $\begin{array}{c}\text { Means differences } \\
(p \text {-value })\end{array}$ \\
\cline { 2 - 4 } Whole sample & 0,23 & 0,53 & $-0,3$ \\
Quarterly & $(0.01)$ & $(0.02)$ & $(0.04)$ \\
& 0,34 & 0,4 & -0.06 \\
Annual & $(0.01)$ & $(0.01)$ & $(0.01)$ \\
BNDES quarterly & 0,68 & 0,86 & $-0,22$ \\
BNDES annual & $(0.01)$ & $(0.04)$ & $(0.08)$ \\
& 0,19 & 0,29 & $-0,1$ \\
& $0.14)$ & $(0.05)$ & $(0.09)$ \\
& 0,34 & 0,53 & $-0,19$ \\
& $(0.02)$ & $(0.06)$ & $(0.01)$ \\
\hline
\end{tabular}

In Table 4, we present the results of the estimation of state equation (4). We are interested in the sign of the following regressors: SELIC, the dummy variable of the FR firms alone and its interaction with the SELIC rate, and the interaction between the SELIC rate, the FR variable, and the BNDES dummy variable.

\footnotetext{
${ }^{27}$ All of our balance sheet variables are normalized by the total assets of the firm. Therefore, the averages presented in Table 2 can be compared to some proxy of EFP, such as the coverage ratio divided by total assets. Oliveira and Ronchi (2012) show that the order of magnitude of these ratios for Brazil is similar to the one presented in Table 2.
} 
If the balance sheet explanation of the monetary policy is relevant, the coefficients of SELIC and of the small firms and the interaction between the two are positive and significant. Due to the Brazilian credit market characteristics, we would also expect the coefficient variable of the interaction between BNDES, small firms, and SELIC to be negative and significant.

The first column of Table 4 presents the averages ( $p$-values in parentheses) of the coefficients of all firms in the sample. As one can see, all coefficients have signs in accordance with the balance sheet explanation and are significant in all estimations for all types of firms.

The second and third columns of Table 4 present the averages ( $p$-values in parentheses) of the estimated parameters for firms that have quarterly information and for those firms with only annual information, respectively. Once again, the coefficients have the appropriate sign and are statistically significant.

Table 4

EFP and Monetary Policy: Averages of the Estimated Coefficients

Our sample is composed of 291 non-financial public corporations and 4,735 private firms. Our sample period goes from the third quarter of 1994 to the fourth quarter of 2010. Among the private firms, 102 disclose quarterly information as well as yearly information while all the others disclose yearly information only. The information on public corporations comes from the Brazilian Securities and Exchange Commission (CVM) and Economatica, the information on private firms comes from Valor Econômico, and confidential information from SERASA and Gazeta Mercantil. We consider a firm as non-financially constrained if the predicted KZ is above the 70th percentile in at least one quarter or year of our sample period and if it has never been below the 30th percentile in any quarters or years. We consider firms to be financially constrained if the predicted $\mathrm{KZ}$ is below the 30th percentile in any quarter or year of our sample period and if it has never been above the 70th percentile in any quarters or years. The table presents the average of the coefficients estimated for the state equation. The $p$-values of the standard $t$ tests are in parentheses.

\begin{tabular}{lccc}
\hline & \multicolumn{3}{c}{ EFP } \\
\cline { 2 - 4 } & Whole sample & Quarterly data & Annual data \\
\hline Constant & 0,35 & 0,56 & $-0,51$ \\
\multirow{3}{*}{ Sum SELIC } & $(0.02)$ & $(0.48)$ & $(0.42)$ \\
& 0,051 & 0,001 & 0,39 \\
FR & $(0.00)$ & $(0.03)$ & $(0.02)$ \\
Sum FR*SELIC & 0,042 & 0,012 & 0,012 \\
& $(0.06)$ & $(0.02)$ & $(0.04)$ \\
Sum BNDES*FR*SELIC & 0,03 & 0,19 & 0,03 \\
& $(0.01)$ & $(0.02)$ & $(0.03)$ \\
Control Variables & $-0,05$ & $-0,07$ & $-0,02$ \\
Sample & $(0.07)$ & $(0.01)$ & $(0.06)$ \\
& & &
\end{tabular}


Panels A, B, and C of Table 5 present the averages ( $p$-values in parentheses) of the estimated coefficients of the signal equations, that is, the dynamics of inventories/assets, short-term debt/, and net operating revenues/assets for aggregate data of all types of firms.

For the dynamics of inventories/assets and short-term debt/assets, we are interested in the sign of the following coefficients: the sum of the EFP coefficients; SELIC; the dummy variable of FR firms alone and its interaction with the SELIC rate; and the interaction between the SELIC rate, the $\mathrm{FR}$ variable, and the $\mathrm{BN}$ DES dummy variable. If the balance sheet explanation of the monetary policy is consistent, the sum of EFP coefficients, the SELIC and FR coefficients, and the interaction between the two are positive and significant. Due to the Brazilian credit market characteristics, we would expect the coefficient variable between BNDES, FR, and SELIC to be negative and significant. As one can observe in Panels A and B of Table 5, all coefficients have the appropriate sign and are statistically significant.

For the dynamics of net operating revenues/assets, we are interested in the sign of the following coefficients: the sum of EFP coefficients; the SELIC coefficients; the dummy variable of the FR firms alone and its interaction with the SELIC rate, and the interaction between the SELIC rate, the FR variable, and the BNDES dummy variable. If the balance sheet explanation of the monetary policy is relevant, the sum of the EFP coefficients, of the SELIC and FR coefficients, and the interaction between the two are negative and significant. Once again, due to the Brazilian credit market characteristics, we would expect the coefficient variable between BNDES, FR, and SELIC to be positive and significant. As one can observe in Panel $\mathrm{C}$ of Table 4, all coefficients have the appropriate sign and are statistically significant. 
Table 5

EFP and the Business Cycle: Averages of the Estimated Coefficients

Our sample is composed of 291 non-financial public corporations and 4,735 private firms. Our sample period goes from the third quarter of 1994 to the fourth quarter of 2010. Among the private firms, 102 disclose quarterly information as well as yearly information while all the others disclose yearly information only. The information on public corporations comes from the Brazilian Securities and Exchange Commission (CVM) and Economatica, the information on private firms comes from Valor Econômico, and confidential information from SERASA and Gazeta Mercantil. We consider a firm as non-financially constrained if the predicted $\mathrm{KZ}$ is above the 70th percentile in at least one quarter or year of our sample period and if it has never been below the 30th percentile in any quarters or years. We consider firms to be financially constrained if the predicted $\mathrm{KZ}$ is below the 30th percentile in any quarter or year of our sample period and if it has never been above the 70th percentile in any quarters or years. Panel A presents the estimation results for the dynamics related to inventories/assets. Panel B presents the estimation results for the dynamics related to the aggregate value of short-term debt/assets. Panel $\mathrm{C}$ presents the results for the dynamics related to net operating revenues/assets. The $p$-values of standard $t$ tests are shown in parentheses.

\begin{tabular}{|c|c|c|c|}
\hline \multicolumn{4}{|c|}{ Panel A - Inventories/Assets } \\
\hline & \multicolumn{3}{|c|}{ EFP } \\
\hline & Whole sample & Quarterly data & Annual data \\
\hline \multirow[t]{2}{*}{ Constant } & 0,26 & 0,57 & 0,32 \\
\hline & $(0.38)$ & $(0.16)$ & $(0.68)$ \\
\hline \multirow[t]{2}{*}{ Sum SELIC } & 0,19 & 0,18 & 0,58 \\
\hline & $(0.03)$ & $(0.34)$ & $(0.17)$ \\
\hline \multirow[t]{2}{*}{ Sum BNDES.SELIC.FR } & $-0,26$ & $-0,01$ & $-0,02$ \\
\hline & $(0.14)$ & $(0.08)$ & $(0.43)$ \\
\hline \multirow[t]{2}{*}{ FR } & 0,65 & 0,49 & 0,68 \\
\hline & $(0.02)$ & $(0.01)$ & $(0.03)$ \\
\hline \multirow[t]{2}{*}{ Sum FR*SELIC } & 0,36 & 0,53 & 0,56 \\
\hline & $(0.14)$ & $(0.04)$ & $(0.04)$ \\
\hline \multicolumn{4}{|l|}{ Sum EFP } \\
\hline & 0,18 & 0,77 & 0,28 \\
\hline & $(0.02)$ & $(0.23)$ & $(0.03)$ \\
\hline \multicolumn{4}{|l|}{ Control Variables } \\
\hline Sample & \multicolumn{3}{|c|}{ 1994Q3 to $2010 \mathrm{Q} 4$} \\
\hline
\end{tabular}


Panel B - Short-Term Debt/Assets

\begin{tabular}{lccc}
\multicolumn{4}{c}{ Panel B - Short-Term Debt/Assets } \\
\cline { 2 - 4 } & Whole sample & Quarterly data & Annual data \\
\cline { 2 - 4 } Constant & $-0,16$ & $-0,46$ & $-0,32$ \\
\multirow{2}{*}{ Sum SELIC } & $(0.42)$ & $(0.18)$ & $(0.42)$ \\
& 0,18 & 0,18 & 0,37 \\
FR & $(0.03)$ & $(0.02)$ & $(0.63)$ \\
\multirow{2}{*}{ Sum FR.SELIC } & 0,94 & 0,56 & 0,55 \\
& $(0.46)$ & $(0.06)$ & $(0.37)$ \\
Sum BNDES.SELIC.FR & 0,46 & 0,68 & 0,47 \\
\multirow{2}{*}{ Sum EFP } & $(0.01)$ & $(0.05)$ & $(0.06)$ \\
& $-0,44$ & $-0,46$ & $-0,47$ \\
Control Variables & $(0.01)$ & $(0.34)$ & $(0.08)$ \\
Sample & 0,28 & 0,36 & 0,29 \\
& $(0.07)$ & $(0.07)$ & $(0.39)$ \\
\hline
\end{tabular}

Panel C - Net Operating Revenues/Assets

\begin{tabular}{lccc}
\hline & \multicolumn{3}{c}{ EFP } \\
\cline { 2 - 4 } Constant & Whole sample & Quarterly data & Annual data \\
\hline \multirow{2}{*}{ Sum SELIC } & $-0,46$ & $-0,74$ & $-0,44$ \\
& $(0.27)$ & $(0.49)$ & $(0.75)$ \\
FR & $-0,18$ & $-0,12$ & 0,48 \\
& $(0.03)$ & $(0.21)$ & $(0.66)$ \\
Sum SELIC.FR & $-0,26$ & $-0,28$ & $-0,57$ \\
& $(0.08)$ & $(0.48)$ & $(0.05)$ \\
Sum BNDES.SELIC*FR & $-0,51$ & $-0,79$ & $-0,88$ \\
\multirow{2}{*}{ Sum EFP } & $(0.03)$ & $(0.13)$ & $(0.13)$ \\
& 0,28 & 0,58 & 0,68 \\
Control Variables & $(0.43)$ & $(0.02)$ & $(0.03)$ \\
Sample & $-0,35$ & $-0,48$ & $-0,31$ \\
& $(0.05)$ & $(0.06)$ & $(0.15)$ \\
\end{tabular}


In a first attempt to test the robustness of our results, we estimated the state space model using dummies for financial crises in Brazil during our sample period, both in the state and signal equations. We consider the following crises: the Asian Crisis (1997Q3 to 1997Q4), the Russian Crisis (1998Q3 to 1998Q4), President Lula's election (2002Q2 to 2002Q4), and the subprime crisis (2008Q1 to 2008Q3). Panel A of Table 6 presents the averages ( $p$-values in parentheses) of the estimated coefficients of the state equation. As one can see, all coefficients have signs in accordance with the balance sheet explanation and are significant in all estimations for all types of firms. Panels B, C, and D present the averages ( $p$-values in parentheses) of the estimated coefficients of the signal equations, that is, the dynamics of inventories/assets, short-term debt/, and net operating revenues/assets for the estimations of firms with quarterly data only. The reported coefficients are averages of the coefficients of all firms. As one can see, once again, all coefficients have the appropriate sign (as discussed above) and are statistically significant.

The results for the dynamics of the three variables - inventories/assets, net operating revenues/assets, and short-term debt/assets - indicate that small and large public firms react very differently to monetary policy. Small firms seem to be more sensitive to monetary policy than large firms. 
Table 6

EFP and the Business Cycle: Using Financial Crises Dummies in Brazil in State and Signal Equations

Our sample is composed of 393 firms with quarterly information. Of these, 291 are non-financial public corporations and 102 are private firms. Our sample period goes from the third quarter of 1994 to the fourth quarter of 2010. The information on public corporations comes from the Brazilian Securities and Exchange Commission (CVM) and Economatica, the information on private firms comes from Valor Econômico, and confidential information from SERASA and Gazeta Mercantil. We consider a firm as non-financially constrained if the predicted KZ is above the 70th percentile in at least one quarter or year of our sample period and if it has never been below the 30th percentile in any quarters or years. We consider firms to be financially constrained if the predicted $\mathrm{KZ}$ is below the 30th percentile in any quarter or year of our sample period and if it has never been above the 70th percentile in any quarters or years. Panel A presents the averages of the coefficients estimated for the dynamics related to EFP. Panel B presents the averages of the coefficients estimated for the dynamics related to inventories/assets. Panel $\mathrm{C}$ presents the averages of the estimated coefficients for the dynamics related to short-term debt/assets. Panel $\mathrm{D}$ presents the averages of coefficients for the dynamics related to net operating revenues/assets. The $p$-values of the standard $t$ tests are shown in parentheses.

Panel A - EFP

\begin{tabular}{lccc}
\hline & \multicolumn{3}{c}{ EFP } \\
\cline { 2 - 4 } & Whole sample & Quarterly data & Annual data \\
\hline Constant & 0,25 & 0,44 & $-0,48$ \\
Sum SELIC & $(0.48)$ & $(0.72)$ & $(0.28)$ \\
& 0,067 & 0,012 & 0,32 \\
FR & $(0.09)$ & $(0.18)$ & $(0.01)$ \\
& 0,01 & 0,032 & 0,024 \\
Sum FR*SELIC & $(0.28)$ & $(0.06)$ & $(0.16)$ \\
Sum BNDES*FR*SELIC & 0,04 & 0,24 & 0,12 \\
& $(0.03)$ & $(0.05)$ & $(0.02)$ \\
Control Variables & $-0,05$ & $-0,06$ & $-0,01$ \\
Sample & $(0.06)$ & $(0.07)$ & $(0.12)$ \\
\hline
\end{tabular}


Panel B - Inventories/Assets

\begin{tabular}{lccc}
\hline & \multicolumn{3}{c}{ EFP } \\
\cline { 2 - 4 } Constant & Whole sample & Quarterly data & Annual data \\
\hline \multirow{3}{*}{ Sum Selic } & $-0,14$ & $-0,44$ & $-0,49$ \\
& $(0.44)$ & $(0.23)$ & $(0.79)$ \\
FR & $-0,12$ & $-0,32$ & 0,32 \\
& $(0.02)$ & $(0.12)$ & $(0.67)$ \\
Sum SELIC.FR & 0,31 & 0,42 & 0,85 \\
Sum BNDES. FR.SELIC & $(0.02)$ & $(0.01)$ & $(0.28)$ \\
& 1,72 & 2,68 & 2,18 \\
Sum EFP & $(0.11)$ & $(0.12)$ & $(0.34)$ \\
Control Variables & $-0,03$ & $-0,47$ & $-0,32$ \\
Sample & $(0.02)$ & $(0.01)$ & $(0.01)$ \\
& 0,66 & 0,42 & 0,78 \\
& $(0.02)$ & $(0.01)$ & $(0.02)$ \\
\hline
\end{tabular}

Panel C - Short-Term Debt/Assets

\begin{tabular}{lccc}
\hline & \multicolumn{3}{c}{ EFP } \\
\cline { 2 - 4 } Constant & Whole sample & Quarterly data & Annual data \\
\cline { 2 - 4 } Sum Selic & $-0,11$ & $-0,47$ & $-0,43$ \\
& $(0.36)$ & $(0.29)$ & $(0.75)$ \\
FR & $-0,11$ & $-0,12$ & 0,46 \\
& $(0.03)$ & $(0.01)$ & $(0.78)$ \\
Sum SELIC.FR & 0,89 & 0,68 & 0,56 \\
& $(0.03)$ & $(0.04)$ & $(0.18)$ \\
Sum BNDES.FR.SELIC & 1,76 & 1,23 & 1,67 \\
\multirow{2}{*}{ Sum EFP } & $(0.02)$ & $(0.46)$ & $(0.04)$ \\
& 0,32 & 0,79 & 0,67 \\
Control Variables & $(0.97)$ & $(0.45)$ & $0.08)$ \\
Sample & 0,46 & 0,67 & 0,46 \\
& $(0.04)$ & $(0.04)$ & $(0.16)$ \\
& \multicolumn{3}{c}{$1994 \mathrm{Q} 3$ to 2010Q4 } \\
\end{tabular}




\begin{tabular}{lccc}
\multicolumn{4}{c}{ Panel D - Net Operating Revenues / Assets } \\
\cline { 2 - 4 } & \multicolumn{3}{c}{ EFP } \\
\cline { 2 - 4 } Constant & $-0,13$ & $-0,78$ & $-0,46$ \\
\multirow{2}{*}{ Sum Selic } & $(0.31)$ & $(0.19)$ & $(0.26)$ \\
& $-0,14$ & $-0,05$ & $-0,37$ \\
FR & $(0.13)$ & $(0.01)$ & $(0.02)$ \\
\multirow{2}{*}{ Sum SELIC.FR } & $-0,45$ & $-0,57$ & $-0,97$ \\
Sum BNDES.FR.SELIC & $(0.02)$ & $(0.02)$ & $(0.01)$ \\
& $-1,38$ & $-2,67$ & $-2,19$ \\
Sum EFP & $(0.02)$ & $(0.19)$ & $(0.01)$ \\
Control Variables & 0,48 & 0,95 & 0,37 \\
Sample & $(0.02)$ & $(0.02)$ & $(0.14)$ \\
& $-0,29$ & $-0,47$ & $-0,37$ \\
& $(0.06)$ & $(0.03)$ & $(0.18)$ \\
\hline
\end{tabular}

In the second attempt to test the robustness of our results, we made some identification assumptions. We considered the coefficient of all the regressors that include the same FR variable for all firms to decrease the number of parameters to be estimated. Panels A to D of Table 7, where we show the averages for the SELIC regressor ( $p$-values in parentheses) and values ( $p$-values in parentheses), estimate the coefficients of the regressors that include FR. The results are again very similar to the ones shown in Tables 4,5 , and 6 . They, therefore, reinforce the relevance of the balance sheet explanation of monetary policy in Brazil. 
Table 7

EFP and the Business Cycle: Coefficients of Small Regressors equal for all firms

Our sample is composed of 393 firms with quarterly information. Of these, 291 are non-financial public corporations and 102 are private firms. Our sample period goes from the third quarter of 1994 to the fourth quarter of 2010. The information on public corporations comes from the Brazilian Securities and Exchange Commission (CVM) and Economatica, the information on private firms comes from Valor Econômico, and confidential information from SERASA and Gazeta Mercantil. We take all the coefficients of regressors that include small firms as equal and constant. We consider a firm as non-financially constrained if the predicted KZ is above the 70th percentile in at least one quarter or year of our sample period and if it has never been below the 30th percentile in any quarters or years. We consider firms to be financially constrained if the predicted $\mathrm{KZ}$ is below the 30th percentile in any quarter or year of our sample period and if it has never been above the 70th percentile in any quarters or years. Panel A presents the averages of the coefficients estimated for the dynamics related to EFP. Panel B presents the averages of the coefficients estimated for the dynamics related to inventories/assets. Panel $\mathrm{C}$ presents the averages of the estimated coefficients for the dynamics related to short-term debt/assets. Panel $\mathrm{D}$ presents the averages of coefficients for the dynamics related to net operating revenues/assets. The $p$-values of the standard t tests are shown in parentheses.

\begin{tabular}{lccc}
\multicolumn{4}{c}{ Panel A - EFP } \\
\hline & \multicolumn{3}{c}{ EFP } \\
\cline { 2 - 4 } & Whole sample & Quarterly data & Annual data \\
\hline Constant & 0,24 & 0,56 & $-0,54$ \\
SumSELIC & $(0.12)$ & $(0.65)$ & $(0.26)$ \\
FR & 0,032 & 0,02 & 0,27 \\
Sum FR*SELIC & $(0.02)$ & $(0.16)$ & $(0.12)$ \\
& 0,052 & 0,02 & 0,035 \\
Sum BNDES*FR*SELIC & $(0.07)$ & $(0.03)$ & $(0.02)$ \\
& 0,02 & 0,15 & 0,01 \\
Control Variables & $(0.01)$ & $(0.24)$ & $(0.01)$ \\
Sample & $-0,074$ & $-0,02$ & $-0,01$ \\
& $(0.01)$ & $(0.04)$ & $(0.04)$ \\
& & & \\
\end{tabular}


Panel B - Inventories/Assets

\begin{tabular}{|c|c|c|c|}
\hline & \multicolumn{3}{|c|}{$\mathrm{EFP}$} \\
\hline & Whole sample & Quarterly data & Annual data \\
\hline \multirow[t]{2}{*}{ Constant } & $-0,13$ & $-0,52$ & $-0,27$ \\
\hline & $(0.27)$ & $(0.64)$ & $(0.68)$ \\
\hline \multirow[t]{2}{*}{ SumSelic } & $-0,16$ & $-0,43$ & 0,34 \\
\hline & $(0.15)$ & $(0.04)$ & $(0.42)$ \\
\hline \multirow[t]{2}{*}{ FR } & 0,48 & 0,53 & 0,92 \\
\hline & $(0.18)$ & $(0.02)$ & $(0.01)$ \\
\hline \multirow[t]{2}{*}{ Sum SELIC.FR } & 1,74 & 2,71 & 2,34 \\
\hline & $(0.01)$ & $(0.32)$ & $(0.02)$ \\
\hline \multirow[t]{2}{*}{ Sum BNDES. FR.SELIC } & $-0,16$ & $-0,57$ & $-0,66$ \\
\hline & $(0.01)$ & $(0.02)$ & $(0.16)$ \\
\hline \multirow[t]{2}{*}{ Sum EFP } & 0,45 & 0,44 & 0,93 \\
\hline & $(0.02)$ & $(0.02)$ & $(0.02)$ \\
\hline \multicolumn{4}{|l|}{ Control Variables } \\
\hline Sample & \multicolumn{3}{|c|}{$1994 \mathrm{Q} 3$ to $2010 \mathrm{Q} 4$} \\
\hline
\end{tabular}

Panel C - Short-Term Debt/Assets

\begin{tabular}{|c|c|c|c|}
\hline & \multicolumn{3}{|c|}{ EFP } \\
\hline & Whole sample & Quarterly data & Annual data \\
\hline \multirow[t]{2}{*}{ Constant } & $-0,12$ & $-0,64$ & $-0,54$ \\
\hline & $(0.57)$ & $(0.29)$ & $(0.83)$ \\
\hline \multirow[t]{2}{*}{ Sum Selic } & $-0,12$ & $-0,02$ & 0,26 \\
\hline & $(0.02)$ & $(0.02)$ & $(0.21)$ \\
\hline \multirow[t]{2}{*}{ FR } & 0,67 & 0,68 & 0,18 \\
\hline & $(0.02)$ & $(0.02)$ & $(0.10)$ \\
\hline \multirow[t]{2}{*}{ Sum SELIC.FR } & 1,54 & 2,68 & 2,72 \\
\hline & $(0.02)$ & $(0.17)$ & $(0.02)$ \\
\hline \multirow[t]{2}{*}{ Sum BNDES.FR.SELIC } & 0,54 & 0,38 & 0,79 \\
\hline & $(0.79)$ & $(0.49)$ & $(0.28)$ \\
\hline \multirow[t]{2}{*}{ Sum EFP } & 0,46 & 0,74 & 0,29 \\
\hline & $(0.02)$ & $(0.02)$ & $(0.01)$ \\
\hline \multicolumn{4}{|l|}{ Control Variables } \\
\hline Sample & \multicolumn{3}{|c|}{$1994 \mathrm{Q} 3$ to $2010 \mathrm{Q} 4$} \\
\hline
\end{tabular}


Panel D - Net Operating Revenues/Assets

\begin{tabular}{lccc}
\hline & \multicolumn{3}{c}{ EFP } \\
\cline { 2 - 4 } & Whole sample & Quarterly data & Annual data \\
\hline Constant & $-0,11$ & $-0,74$ & $-0,48$ \\
Sum Selic & $(0.36)$ & $(0.38)$ & $(0.38)$ \\
& $-0,13$ & $-0,16$ & $-0,37$ \\
FR & $(0.02)$ & $(0.02)$ & $(0.03)$ \\
& $-0,47$ & $-0,56$ & $-0,36$ \\
Sum SELIC.FR & $(0.01)$ & $(0.02)$ & $(0.01)$ \\
Sum BNDES.FR.SELIC & $-1,47$ & $-2,54$ & $-2,19$ \\
& $(0.02)$ & $(0.48)$ & $(0.29)$ \\
Sum EFP & 0,42 & 0,96 & 0,72 \\
& $(0.01)$ & $(0.04)$ & $(0.33)$ \\
Control Variables & $-0,14$ & $-0,42$ & $-0,28$ \\
Sample & $(0.02)$ & $(0.02)$ & $(0.18)$ \\
& & & \\
\hline
\end{tabular}

We ran several other robustness tests, but we do not report them because of space restrictions: we used several different specifications for the state equations; in the case of signal equations, we used lags of EFP only; we used the growth rate of BOVESPA and IBRX as control variables in the backcasting estimations; we used medians instead of averages for the coefficients estimated in Tables 3 to 5; we included a control variable that indicates a financial crisis in Brazil in our sample period in the state and signal equations; instead of backcasting the model first, we used the Kalman filter directly with missing observations; finally, we decreased the number of small firms in all estimations presented above so that it would match the number of large firms. In general terms, the results presented above do not change.

All our empirical results above seem to show a relevant asymmetry in the reaction of small and large firms to monetary contractions. This asymmetry reflects different access of Brazilian corporations to the financial markets. Large public and private firms have more financing alternatives than do their small counterparts and therefore are able to suffer less discontinuity in terms of investment, revenues, and short-term financing after monetary contractions.

Since the borrowers' financial position affects their external premium and thus the overall terms of credit they face, fluctuations in the quality of borrowers' balance sheets should likewise affect their investment and spending decisions.

This approach has been supported by a wide range of empirical works linking balance sheet and cash flow variables to firms' decisions concerning fixed investments, inventories, and other factor demands, as well as to household purchases of durables and housing.

The balance sheet channel of monetary policy arises because shifts in the central bank policy not only affect the market interest rate per se, but also the borrowers' 
financial positions, both directly and indirectly. Our paper is in line with this overall empirical evidence of the literature for OECD countries.

\section{Conclusion}

This paper investigates the balance sheet explanation of the monetary transmission mechanism in Brazil. One problem to investigate this is that a fundamental variable for this purpose, EFP, is non-observable. This paper contributes to the literature by estimating the EFP of firms in Brazil using state space models.

Our estimations are based on an original database with confidential and public data containing information on 5,026 public and private firms from the third quarter of 1994 to the fourth quarter of 2010.

Our results show that the EFP average and volatility of financially constrained firms are higher than those of non-financially constrained firms and that EFP is more sensitive to monetary policy for financially constrained firms than for non-financially constrained ones. We also found that the elasticity of EFP in relation to inventories, short-term debt, and net operating revenues, all of them as a proportion of total assets, is higher for financially constrained firms than for non-financially constrained ones. This empirical evidence points to the importance of the balance sheet channel as an explanation for the transmission mechanism of monetary policy in Brazil.

Our results indicate that small firms are much more sensitive to monetary policy than large firms and that BNDES plays a relevant role in decreasing this sensitivity. The results are robust to several different specifications of the space model.

Non-financially constrained firms in Brazil, which are likely to obtain loans from BNDES, respond to an unanticipated decline in cash flows in a different manner from financially constrained firms. They can, at least temporally, be able to maintain their levels of production and employment in view of higher interest costs and declining revenues through other sources of short-term and longterm financing. However, this is not the case for financially constrained firms. These firms, which have more limited access to the financial markets, tend to lose inventories and revenues and to cut working hours and production.

These differences in access have many possible reasons. Some have to do with a bankruptcy legislation that makes it difficult for creditors to size the assets of firms. Others relate to high spreads that are still prevalent in Brazil. Another reason as well may be related to a segmented credit market, where long-term financing basically comes from BNDES and is much easier for non-financially constrained firms, which meet the necessary requirements for the loans. 


\section{References}

Asker, J., Messe-Farre, J., \& Ljungqvist, A. (2015). Corporate investment and stock market listing: A puzzle. Review of Financial Studies, 28:342-390.

Bernanke, B., Gertler, M., \& Gilchrist, S. (1999). The financial accelerator in a quantitative business cycle framework. In Taylor, J. \& Woodford, M., editors, Handbook of Macroeconomics, volume 1C. Elsevier Science, North Holland.

Bernanke, B. S. \& Gertler, M. (1995). Inside the black box: The credit channel of monetary policy transmission mechanism. Journal of Economic Perspectives, 9:27-48.

Brock, W., Dechert, W., Scheinkman, J., \& LeBaron, B. (1996). A test for independence based on the correlation dimension. Econometric Reviews, 15:197-235.

Chow, C. G. \& Lin, A. (1971). Best linear unbiased interpolation, distribution and extrapolation of time series by related series. The Review of Economic and Statistics, 53:372-375.

Fazzari, S. M., Hubbard, R. G., \& Petersen, B. C. (1988). Financing constraints and corporate investment. Brookings Papers on Economic Activity, pages 141206.

Gertler, M. \& Gilchrist, S. (1994). Monetary policy, business cycles and the behaviour of small manufacturing firms. The Quarterly Journal of Economics, 109:309-340

Gilchrist, S. \& Hilmlberg, C. P. (1998). Investment, fundamentals, and finance. NBER Working paper series 6652, National Bureau of Economic Research.

Gilchrist, S. \& Himmelberg, C. P. (1995). Evidence on the role of cash flow for investment. Journal of Monetary Economics, 36:541-572.

Graeve, F. D. (2008). The external finance premium and the macroeconomy: US post-WWII Evidence. Working Paper 0809, Federal Reserve Bank of Dallas.

Harvey, A. C. \& Pierce, R. G. (1984). Estimating missing observations in economic time series. Journal of the American Statistical Association, 79:125-31.

Harvey, C. A. (1994). Time Series Analysis. MIT Press.

IBGE (2010). Instituto brasileiro de geografia e estatística. www.ibge.gov .br.

Issler, J. V., Notini, H. H., \& Rodrigues, F. C. (2009). Um indicador coincidente e antecedente da atividade econômica brasileira. Technical Report Ensaios Econômicos, FGV. 
Jarque, C. M. \& Bera, A. K. (1980). Efficient tests for normality, homoscedasticity and serial independence of regression residuals. Economics Letters, 6:255-259.

Jensen, C. M. \& Meckling, H. W. (1976). Theory of the firm: Managerial behavior, agency costs and ownership structure. Journal of Financial Economics, 3:305360 .

Kaplan, S. N. \& Zingales, L. (1997). Do investment-cash flow sensitivities provide useful measures of financing constraints? Quarterly Journal of Economics, 112:169-215.

Levin, A., Natalucci, F., \& Zakrajsek, E. (2004). The magnitude and cyclical behaviour of financial market frictions. Working Paper 2004-70, Board of Governors of the Federal Reserve System.

Mody, A. \& Taylor, M. (2004). Financial predictors of real activity and the financial accelerator. Economics Letters, 82:167-172.

Myers, S. (1977). Determinants of corporate borrowing. Journal of Financial Economics, 3:147-175.

Ogawa, K. \& Iiboshi, H. (2008). Does the agency cost model explain business fluctuation in Japan? A bayesian approach to estimate agency costs for firms classified by size. Journal of Japan Statistical Society, 38:349-378.

Oliveira, F. N. (2009). Effects of monetary policy on corporations in Brazil: An empirical analysis of the balance sheet channel. Brazilian Review of Econometrics, 29:171-204.

Oliveira, F. N. \& Ronchi, A. (2012). An empirical analysis of the external finance premium of public non-financial corporations in Brazil. Revista Brasileira de Economia, 66:323-360.

Peyrache, A. \& Rambaldi, A. N. (2012). A state space stochastic frontier panel data model. Working Paper 01, Centre for Efficiency and Productivity Analysis.

Rajan, R. G. \& Zingales, L. (1995). What do we know about capital structure? Some evidence from international data. Journal of Finance, 50:1421-60.

Silva, S. M. J. \& Cardoso, F. N. (2001). The Chow-Lin model using dynamic models. Economic Modelling, 18:269-280.

Smith, W. C. \& Stuulz, M. R. (1985). The determinants of firms hedging policies. Journal of Financial and Quantitative Analysis, 20:391-405. 


\section{Appendix A}

In this appendix, we demonstrate Propositions 1 and 2 described in the text. Our model adapts the part of the BGG (1999) model related to the decision of the entrepreneur to the Brazilian credit market. The idea is to model this decision using the costly state verification (CSV) mechanism.

It is a static partial equilibrium model related to the decision of the firm to maximize expected profit. We have a continuum of firms and two types of lenders, a market lender and another lender, a social development bank (BNDES). There is no aggregate risk.

The following are definitions of the variables we use.

\section{Definitions}

$P_{B}=$ Probability Loan - BNDES

$w_{B}=$ productivity shock of BNDES loan

$w_{M}=$ productivity shock of market loan

$\bar{w}_{B}=$ default cutoff - BNDES

$\bar{w}_{M}=$ default cutoff - market

$f_{B}(w)=$ density probability default of loan obtained from BNDES

$f_{M}(w)=$ density probability default of loan obtained at market bank

$\mu_{B}(w)=$ monitoring costs - BNDES

$\mu_{M}(w)=$ monitoring costs - market

$\Gamma_{B}\left(\bar{w}_{B}\right)=$ expected gross share profits going to BNDES

$\Gamma_{M}\left(\bar{w}_{M}\right)=$ expected gross share profits going to market bank

$\mu_{B} G_{B}\left(\bar{w}_{B}\right)=$ expected monitoring costs - BNDES

$\mu_{M} G_{M}\left(\bar{w}_{M}\right)=$ expected monitoring costs - market bank

$$
\begin{gathered}
\Gamma_{B}\left(\bar{w}_{B}\right)=\int_{0}^{\bar{w}_{B}} w f_{B}(w) d w+\bar{w}_{B} \int_{\bar{w}_{B}}^{\infty} f_{B}(w) d w \\
\Gamma_{M}\left(\bar{w}_{M}\right)=\int_{0}^{\bar{w}_{B}} w f_{M}(w) d w+\bar{w}_{M} \int_{\bar{w}_{B}}^{\infty} f_{M}(w) d w
\end{gathered}
$$

Given the definitions above, one can see that:

$$
\begin{aligned}
\Gamma_{B}^{\prime} & =1-F_{B}\left(\bar{w}_{B}\right) \\
\Gamma_{B}^{\prime \prime} & =1-F_{B}\left(\bar{w}_{B}\right) \\
\Gamma_{M}^{\prime} & =1-F_{B}\left(\bar{w}_{B}\right) \\
\Gamma_{M}^{\prime} & =1-F_{B}\left(\bar{w}_{B}\right) \\
\mu_{B} G_{B}\left(\bar{w}_{B}\right) & =\mu_{B} \int_{0}^{\bar{w}_{B}} w f_{B}(w) d w
\end{aligned}
$$




$$
\mu_{B} G_{B}\left(\bar{w}_{B}\right)=\mu_{B} \int_{0}^{\bar{w}_{B}} w f_{B}(w) d w
$$

The net share profit for BNDES and the market bank are:

$$
\begin{gathered}
\operatorname{BNDES}: \Gamma_{B}\left(\bar{w}_{B}\right)-\mu_{B} G_{B}\left(\bar{w}_{B}\right)>0 \\
\text { Market bank: } \Gamma_{M}\left(\bar{w}_{M}\right)-\mu_{M} G_{M}\left(\bar{w}_{M}\right)>0
\end{gathered}
$$

We have the following transversality conditions:

$$
\begin{gathered}
\lim _{\bar{w}_{B} \rightarrow 0} \Gamma_{B}\left(\bar{w}_{B}\right)-\mu_{B} G_{B}\left(\bar{w}_{B}\right)=0 \\
\lim _{\bar{w}_{B} \rightarrow 0} \Gamma_{M}\left(\bar{w}_{M}\right)-\mu_{M} G_{M}\left(\bar{w}_{M}\right)=0 \\
\lim _{\bar{w}_{B} \rightarrow \infty} \Gamma_{B}\left(\bar{w}_{B}\right)-\mu_{B} G_{B}\left(\bar{w}_{B}\right)=1-\mu_{B} \\
\lim _{\bar{w}_{B} \rightarrow \infty} \Gamma_{M}\left(\bar{w}_{M}\right)-\mu_{M} G_{M}\left(\bar{w}_{M}\right)=1-\mu_{M}
\end{gathered}
$$

The hazard rate for BNDES and market bank loans are the following:

$$
\begin{gathered}
\text { Hazard rate for BNDES }=\frac{f_{B}\left(\bar{w}_{B}\right)}{1-F_{B}\left(\bar{w}_{B}\right)} \\
\text { Hazard rate for market bank }=\frac{f_{M}\left(\bar{w}_{M}\right)}{1-F_{M}\left(\bar{w}_{M}\right)}
\end{gathered}
$$

As one can see, $\bar{w}_{B} h\left(\bar{w}_{B}\right)$ is increasing in $\bar{w}_{B}$ $\bar{w}_{M} h\left(\bar{w}_{M}\right)$ is increasing in $\bar{w}_{M}$

There are global maxima for the net profits of firms that obtain a loan from BNDES and at the market bank.

$$
\Gamma_{B}^{\prime}\left(\bar{w}_{B}\right)-\mu_{B} G_{B}^{\prime}\left(\bar{w}_{B}\right)=\left(1-F\left(\bar{w}_{B}\right)\left(1-\mu_{B} \bar{w}_{B} h\left(\bar{w}_{B}\right)\right)>=<\right.
$$

for $\bar{w}_{B}>w_{B}^{*}$

$$
\Gamma_{M}^{\prime}\left(\bar{w}_{M}\right)-\mu_{M} G_{M}^{\prime}\left(\bar{w}_{M}\right)=\left(1-F\left(\bar{w}_{M}\right)\left(1-\mu_{M} \bar{w}_{M} h\left(\bar{w}_{M}\right)\right)>=<\right.
$$

for $\bar{w}_{M}>w_{M}^{*}$

Proposition 1. Given the structure of the model described above and in the text, EFP is an increasing function of firms' probabilities of default.

Demonstration: A firm has the following problem to solve and it chooses: $K, \bar{w}_{B} \bar{w}_{M}$

$$
\max \left[P_{B}\left(1-\Gamma_{B}\left(\bar{w}_{B}\right)\right)+\left(1-P_{B}\right)\left(1-\Gamma_{M}\left(\bar{w}_{M}\right)\right)\right]_{R} K_{Q K}
$$


s.t.

$$
\begin{gathered}
{\left[\Gamma_{B}\left(\bar{w}_{B}\right)-\mu_{B} G_{B}\left(\bar{w}_{B}\right)\right] R^{K} Q K=\rho R(Q K-N)} \\
{\left[\Gamma_{M}\left(\bar{w}_{M}\right)-\mu_{M} G_{M}\left(\bar{w}_{M}\right)\right] R^{K} Q K=R(Q K-N)}
\end{gathered}
$$

We define

$$
s=\frac{R^{K}}{R}, k=\frac{Q K}{N}, 0<\rho<1
$$

where $s$ is the external finance premium, EFP. Therefore, we have:

$$
\max \left[P_{B}\left(1-\Gamma_{B}\left(\bar{w}_{B}\right)\right)+\left(1-P_{B}\right)\left(1-\Gamma_{M}\left(\bar{w}_{M}\right)\right)\right] s k
$$

s.t.

$$
\begin{gathered}
{\left[\Gamma_{B}\left(\bar{w}_{B}\right)-\mu_{B} G_{B}\left(\bar{w}_{B}\right)\right] \frac{s}{\rho} k=k-1} \\
{\left[\Gamma_{M}\left(\bar{w}_{M}\right)-\mu_{M} G_{M}\left(\bar{w}_{M}\right)\right] s k=k-1}
\end{gathered}
$$

or

$$
\max \left[P_{B}\left(1-\Gamma_{B}\left(\bar{w}_{B}\right)\right)+\left(1-P_{B}\right)\left(1-\Gamma_{M}\left(\bar{w}_{M}\right)\right)\right] s k
$$

s.t.

$$
\left[\Gamma_{B}\left(\bar{w}_{B}\right)-\mu_{B} G_{B}\left(\bar{w}_{B}\right)\right] \frac{s}{\rho} k+\left[\Gamma_{M}\left(\bar{w}_{M}\right)-\mu_{M} G_{M}\left(\bar{w}_{M}\right)\right] s k-2 k+2=
$$

Solution:

$$
L=\left[P_{B}\left(1-\Gamma_{B}\left(\bar{w}_{B}\right)\right)+\left(1-P_{B}\right)\left(1-\Gamma_{M}\left(\bar{w}_{M}\right)\right)\right] s k+
$$

$\lambda\left[\Gamma_{B}\left(\bar{w}_{B}\right)-\mu_{B} G_{B}\left(\bar{w}_{B}\right)\right] \frac{s}{\rho} k+\lambda\left[\Gamma_{M}\left(\bar{w}_{M}\right)-\mu_{M} G_{M}\left(\bar{w}_{M}\right)\right] s k-2 \lambda k+2 \lambda=0$

FOC

(i) $\frac{\partial L}{\partial k}=0 \Rightarrow$

$$
\begin{gathered}
{\left[P_{B}\left(1-\Gamma_{B}\left(\bar{w}_{B}\right)\right)+\left(1-P_{B}\right)\left(1-\Gamma_{M}\left(\bar{w}_{M}\right)\right)\right] s+} \\
\frac{\lambda}{\rho}\left[\Gamma_{B}\left(\bar{w}_{B}\right)-\mu_{B} G_{B}\left(\bar{w}_{B}\right)\right]+\lambda s\left[\Gamma_{M}\left(\bar{w}_{M}\right)-\mu_{M} G_{M}\left(\bar{w}_{M}\right)\right]-2 \lambda=0
\end{gathered}
$$

(ii) $\frac{\partial L}{\partial \bar{w}_{B}}=0 \Rightarrow$

$$
s k P_{B}\left(-\Gamma_{B}^{\prime}\left(\bar{w}_{B}\right)\right)+\frac{\lambda s}{\rho} k\left[\Gamma_{B}^{\prime}\left(\bar{w}_{B}\right)-\mu_{B} G_{B}^{\prime}\left(\bar{w}_{B}\right)\right]=0
$$


(iii) $\frac{\partial L}{\partial \bar{w}_{M}}=0 \Rightarrow$

$$
s k\left(1-P_{B}\right)\left(-\Gamma_{M}^{\prime}\left(\bar{w}_{M}\right)\right)+\lambda s k\left[\Gamma_{M}^{\prime}\left(\bar{w}_{M}\right)-\mu_{M} G_{M}^{\prime}\left(\bar{w}_{M}\right)\right]=0
$$

By combining (ii) and (iii), we have:

$$
\begin{gathered}
\lambda=\frac{P_{B}\left(\Gamma_{B}^{\prime}\left(\bar{w}_{B}\right)\right)+\left(1-P_{B}\right)\left(\Gamma_{M}\left(\bar{w}_{M}\right)\right)}{\frac{1}{\rho}\left(\Gamma_{B}^{\prime}\left(\bar{w}_{B}\right)-\mu_{B} G_{B}^{\prime}\left(\bar{w}_{B}\right)\right)+\Gamma_{M}^{\prime}\left(\bar{w}_{M}\right)-\mu_{M} G_{M}^{\prime}\left(\bar{w}_{M}\right)} \\
\lambda=\lambda\left(P_{B}, \bar{w}_{B}, \bar{w}_{M}, \rho, \mu_{B}, \mu_{M}\right)>0 \\
\frac{\partial \lambda}{\partial \bar{w}_{B}} \frac{1}{\left[\frac{1}{\rho}\left(\Gamma_{B}^{\prime}\left(\bar{w}_{B}\right)-\mu_{B} G_{B}^{\prime}\left(\bar{w}_{B}\right)\right)+\Gamma_{M}^{\prime}\left(\bar{w}_{M}\right)-\mu_{M} G_{M}^{\prime}\left(\bar{w}_{M}\right)\right]^{2}} \\
{\left[\begin{array}{l}
P_{B} \Gamma^{\prime \prime}\left(\bar{w}_{B}\right) \frac{1}{\rho}\left(\Gamma_{B}^{\prime}\left(\bar{w}_{B}\right)-\mu_{B} G_{B}^{\prime}\left(\bar{w}_{B}\right)\right)+\Gamma_{M}^{\prime}\left(\bar{w}_{M}\right)-\mu_{M} G_{M}^{\prime}\left(\bar{w}_{M}\right)- \\
\left(\left(P_{B} \Gamma^{\prime}\left(\bar{w}_{B}\right)\right)+\left(1-P_{B}\right) \Gamma_{M}^{\prime}\left(\bar{w}_{M}\right)\right) \frac{1}{\rho}\left(\Gamma_{B}^{\prime \prime}\left(\bar{w}_{B}\right)-\mu_{B} G_{B}^{\prime \prime}\left(\bar{w}_{B}\right)\right)
\end{array}\right]}
\end{gathered}
$$

It is easy to see that $\frac{\partial \lambda}{\partial \bar{w}_{B}}=0$.

By analogy, $\frac{\partial \lambda}{\partial \bar{w}_{M}}<0$.

Using (i), we have (iv):

(iv)

$$
\begin{gathered}
s=\frac{2 \lambda}{\left[\begin{array}{c}
P_{B}\left(1-\Gamma_{B}\left(\bar{w}_{B}\right)\right)+\left(1-P_{B}\right)\left(1-\Gamma_{M}\left(\bar{w}_{M}\right)\right) \\
+\lambda\left[\frac{\Gamma_{B}\left(\bar{w}_{B}\right)-\mu_{B} G_{B}\left(\bar{w}_{B}\right)}{\rho}+\Gamma_{M}\left(\bar{w}_{M}\right)-\mu_{M} G_{M}\left(\bar{w}_{M}\right)\right]
\end{array}\right]} \\
\frac{\partial s}{\partial \bar{w}_{B}}=\frac{\partial \lambda}{\partial \bar{w}_{B}} \frac{\partial s}{\partial \lambda} . \text { As it is easy to see, } \\
\frac{\partial s}{\partial \lambda}<0 \Rightarrow \frac{\partial s}{\partial \bar{w}_{B}}>0 \Rightarrow \bar{w}_{B}=\bar{w}_{B}(s)
\end{gathered}
$$

Therefore, EFP, is an increasing function of firms' probabilities of default.

Proposition 2. Given the structure of the model described above and in the text, EFP is a decreasing function of the probability of the firm to obtain a loan from $B N D E S$ if the expected profit of BNDES is less than the expected profit of the market lender.

From (iv) above, we have:

$$
\frac{\partial s}{\partial P_{B}}=\frac{-2 \lambda\left(1-\Gamma_{B}\left(\bar{w}_{B}\right)-1-\Gamma_{M}\left(\bar{w}_{M}\right)\right)}{[]^{2}}
$$

where [ ] is the denominator of (iv)

$$
\frac{\partial s}{\partial P_{B}}<0 \Leftrightarrow \Gamma_{B}\left(\bar{w}_{B}\right)<\Gamma_{M}\left(\bar{w}_{M}\right)
$$

